\title{
Gratitude and social support as predictors for fishermen's subjective well-being
}

\author{
Abdul Rahman Shaleh, ${ }^{1 *}$ Anizar Rahayu, ${ }^{2}$ Azlee Zubeir, ${ }^{3}$ Akhlis Istiqlal ${ }^{1}$ \\ ${ }^{1}$ Faculty of Psychology, Universitas Islam Negeri Syarif Hidayatullah, Jakarta - Indonesia; ${ }^{2}$ Faculty of Psychology, \\ Universitas Persada Indonesia YAl, Jakarta - Indonesia; ${ }^{3}$ School of Applied Psychology, Social Work and Policy \\ Universiti Utara Malaysia, Kedah Darul Aman - Malaysia
}

\begin{abstract}
Everybody aspires and deserves some personal well-being. This kind of well-being is subjective, and it is shaped by the way individuals perceive and feel the situations surrounding their lives. This study aimed to investigate the effect of gratitude and social support on fishermen's subjective well-being. This study's subjects were 299 fishermen living in the coastal area of Pelabuhan Ratu, who were chosen through an accidental sampling technique. In collecting data, subjective wellbeing was measured using Flourishing Scale and Scale of Positive and Negative Experience, Gratitude Scale, which was based on Gratitude Resentment and Appreciation Test, and Social Support Scale that was based on Multidimensional Scale of Perceived Social Support. Multiple regression analysis showed that the entire independent variables significantly influenced subjective well-being. Meanwhile, each dimension's regressive coefficient on the independent variables showed four subvariables that significantly influenced the dependent variables: sense of abundance, simple appreciation, appreciation to others, and family support.
\end{abstract}

Keywords: gratitude; Indonesian fishermen; social support; subjective welfare

\begin{abstract}
Abstrak: Semua orang bercita-cita dan pantas mendapatkan kesejahteraan pribadi. Jenis kesejahteraan ini subjektif, dan dibentuk oleh cara individu memandang dan merasakan situasi di sekitar kehidupan mereka. Penelitian ini dimaksudkan untuk menguji keterkaitan antara syukur dan dukungan sosial dengan kesejahteraan subjektif nelayan. Subjek penelitian sejumlah 229 nelayan Pelabuhan Ratu yang diambil dengan teknik accidental sampling. Dalam pengumpulan data, kesejahteraan subjektif diukur dengan Flourishing Scale dan Scale of Positive and Negative Experience, Skala Syukur yang dikembangkan dari Gratitude Resentment and Appreciation Test, dan Skala Dukungan Sosial yang diadaptasi dari Multidimensional Scale of Perceived Social Support. Regresi berganda digunakan sebagai cara untuk menganalisis data dan menunjukkan bahwa keseluruhan variabel bebas memiliki pengaruh yang signifikan terhadap kesejahteraan subjektif dengan sumbangan signifikansi empat subvariabel signifikan terhadap dependen variabel pada koefien regresi, yaitu sense of abundance, simple appreciation, appreciation to others, dan dukungan keluarga.
\end{abstract}

Kata Kunci: syukur; nelayan Indonesia; dukungan sosial; kesejahteraan subjektif *Corresponding Author: Abdul Rahman Shaleh (abd.rahman.shaleh@uinjkt.ac.id), Faculty of Psychology UIN Syarif Hidayatullah
Jakarta, Jl. Kertamukti 5 Cirendeu Ciputat Tangerang Selatan 15419-Indonesia. 


\section{Introduction}

Eight thousand fishing villages adorn Indonesia coastal townships and regencies (district) teeming with an abundance of marine resources, and along with the country's live 800,000 families who make a living from fishing (Dinillah, 2017). With an abundance of maritime resources, people inhabiting Indonesia coastlines and the adjacent areas, especially the fishermen, should enjoy affluent lives. Ironically, the abundance of resources and natural potentials does not necessarily mean that the people living there -especially the fishermen- lead a prosperous life (Dni, 2019). Pelabuhan Ratu, located on Java Island's southern coastal area whose people predominantly work as fishermen, is a perfect example of this predicament. Extreme climactic change is among the factors that bring tremendous pressure on the lives of the local fishermen. Extreme weather change occurs typically between November and December. The west monsoon winds blowing from mainland Asia travels through the oceans and brings a lot precipitation (personal interview, 2019). This situation brings uncertainty among the local fishermen: elemental fluctuations encumber their effort to access the natural resources, and as a consequence, productivity plummeted (Crona et al., 2010). This condition's logical repercussion is the unstable price of supply, loss of an asset, and increased risk of at-sea mortality when fishermen have to brave the ferocious storms. To mitigate the risks of at-sea fatalities, the fishermen usually refrain from catching fish and try to find themselves alternative jobs onshore to alleviate the pressures on their lives (personal interview, 2019).

Those fishermen start their day at four in the morning: they spend two grueling hours to prepare their boats before going to the sea. They prepare their fishing nets and fill the fish storage room with ice from a supplier near the fishing docks. When the supplies and equipment are ready, they start the perilous journey to catch fish on the open sea. When fishing, they have to confront huge waves on the sea. The risk of losing their lives is imminent (personal interview, 2019)

Considering the dire situations that confront them to make ends meet, efforts must be made to promote or safeguard fisher's well-being. Prosperity is everybody's fundamental right, regardless of their ethnic, cultural, social, and occupational backgrounds. Indonesian Law No. 45/2009 defines fishers as people who make a living from catching fish. The law also stipulates things related to their welfare and technical assistance. In light of this, studies on fisher's wellbeing and factor affecting it is necessary to curb their negative behavior and contain the spread of their negative attitudes. Fauzi (2005) explains that fishers have unintentionally extracted the marine resources without considering the sea's capacity in their effort to survive their harsh lives. Additionally, studies on well-being and the quality of life can boost their endurance and performance (see, for example, Hasibuan et al., 2018).

The term 'well-being' refers to an individual or communal conditions related to their satisfaction and the fulfillment of their physical, mental, and social needs. From the psychological perspective, there are at least two viewpoints on well-being, i.e., objective and subjective viewpoints. The objective view originates from Aristotle's philosophical concept of eudaimonia, which explains that wellbeing must be perceived through objective measurement by optimizing the whole potential and guided behavior. Ryff further capitalized on this concept to develop psychological well-being, 
which refers to fulfilling psychological potentials characterized by self-acceptance, aim of life, positive relationship, independence, adaptability and personal growth (Ryff, 1989). Meanwhile, subjective view of well-being has its roots in the hedonic approach, which shows that well-being is subjective. This is in line with the word hedonic that means 'satiated, happy, and spared from suffering. Aristippus, a philosopher from the $4^{\text {th }}$ century, explained that life's very objective is to experience that peak of joy and happiness (Ryan \& Deci, 2001). Therefore, hedonistic psychology focuses on pleasant and unpleasant experiences (Kahneman et al., 1998). In a nutshell, well-being is interpreted as the presence of positive affect dan the absence of negative affect, which can only happen by maximizing an individual's happy feeling (Deci \& Ryan, 2008; Ryan \& Deci, 2001). Diener and Lucas $(1999,2000)$ point out that based on this view, the construct of subjective well-being is developed with three aspects: life satisfaction, the presence of positive affect and the absence of negative affect, and this subjective wellbeing can be attained when individuals make a self-assessment/ judgment about their lives.

Subjective well-being can also mean the way individuals judge their lives, including the way they value what they feel, their moods, and emotions like positive and negative feelings (Bradburn, 1969; Diener et al., 1999; Diener \& Chan, 2011). Tov and Diener (2013) explain that subjective well-being refers to the way individuals judge their lives (Diener, 2009; Diener \& Chan, 2011). A person enjoys subjective well-being when he assigns high values to life satisfaction and low value to negative feelings and high value to positive feelings (Diener \& Chan, 2011; Proctor et al., 2011). Farid and Lazarus (2008) define subjective well-being as individuals' evaluation of things that generally benefit their lives and their occupation as well as their physiological, psychological, and social satisfaction.

Subjective well-being has its cognitive and affective aspects. The cognitive aspect means the way individuals judge global or specific satisfaction (Diener et al., 1999). Global judgment means an individual's judgment or assessment about their lives that reflect their general satisfaction about life. Specific domain evaluation is how an individual assesses specific dimensions of their life (general aspects of life such as health, occupation, social relations, and family (Diener \& Chan, 2011). According to Diener and Lucas (1999), the affective dimension reflects events in someone's life by examining the types of affective reactions. A s a rule of thumb, affective dimension can be categorized into the evaluation of the presence of positive affect and assessment of the negative affect.

Several factors can contribute to subjective well-being: self-esteem (Eddington \& Shuman, 2008), personality (Diener et al., 1999), optimism, perceived social (Diener \& Seligman, 2002), hope (Snyder, 2002) dan gratitude. This current research focused on gratitude and perceived social support.

Several previous studies have shown the relationship between gratitude and subjective well-being (Alkozei, Smith, \& Killgore, 2018; Diebel, Woodcock, Cooper, \& Brignell, 2016; Killen \& Macaskill, 2015; Lai \& O'Carroll, 2017; Waters, 2011). Gratitude is inextricably linked to individuals' mental health and life satisfaction. Grateful persons can experience high subjective well-being. Gratitude has proved to boost positive moods. Gratitude can increase the positive and useful thoughts needed to cope with negative occurrences and combat negative conditions such 
as depression (Watkins et al., 2003). The Oxford English Dictionary (1989) defines gratitude as a quality or condition in which a person is grateful or, to quote Emmons and McCullough (2003) as an appreciation which motivates individuals to return personal favor. According to Wood et al. (2009), gratitude is the characteristic of individuals who think positively and make their life more positive. Gratitude is the way individuals appreciate the favors that they have received. They lack nothing; they recognize other people's contributions to their lives and their appreciation of simple joys (Watkins et al., 2003). Gratitude is frequently expressed by saying "thank you.". Watkins et al. (2003) explicate three dimensions of gratitude: a sense of abundance, simple appreciation, and others' appreciation. Sense of Abundance characterizes individuals with high gratitude and feel satisfied with what they possess in life. They get some sense of abundance, they feel that what they have is enough and useful. Simple appreciation is experienced by individuals who tend to show a high level of gratitude; they enjoy and appreciate something that people commonly and easily have. Enjoying something simple refers to food, technology, dwelling, and the likes. Appreciation of others characterizes individuals who recognize people's help and favor in their lives. Mccullough et al. (2001; 2002) stresses that people's contributions among the factors that trigger gratitude.

Additionally, perceived social support is among the factors that affect an individual's wellbeing. According to Stokes (1985), social support refers to the availability of support when it is needed and this kind of support can be identified subjectively. According to Malecky and Demaray (2002, 2006), social support is the perceived general or specific support individuals get from people in their groups when confronting difficulties in life. Social support is perceived to be the kind of support that is available when necessary (Cohen et al., 2000). Social support helps motivate individuals to cope with problems and changes. Individuals who get social support feel that they are trusted, given attention, loved, valuable, worthy, and belong to their group and feel more capable of putting up with pressure and many kinds of life problems. This perceived support has proved to significantly affect human health. According to Malecky dan Demaray (2002, 2006), there are three aspects of social support: family, friends, and significant others. In addition to that, in this study we adapted Zimet, Dahlem, Zimet and Farley's theory (Zimet et al., 1988) about perceived social support: the kind of support that individuals get from their families, peers and the significant others. Perceived social support is closely related to individuals' subjective well-being (Gülaçt, 2010; Kong et al., 2013; Li et al., 2014; Savelkoul et al., 2000; Siedlecki et al., 2014; Tran \& Wright Jr, 1986).

Based on the above explanation, this study was conducted to hypothesize that gratitude, social support, and the dimensions in each variable significantly affect subjective well-being. This study is significant and unique because it involves groups of fishermen who exhibit high social cohesiveness. But paradoxically, they are fiercely competitive in their social strata (Adriana et al., 2017; Salsabila, 2019). They also show a high degree of gratitude to mother nature as manifested in their annual tradition of larung sesaji (ornate, collective offerings on miniature fishing boats launched to the open sea) (Nashir, 2017).

\section{Method}

This study's samples are fishermen from the village of Pelabuhan Ratu, a coastal area on Java Island. The total number of research samples is 
229 selected through non-probability sampling using the accidental sampling technique.

The variables of the research are subjective well-being, gratitude, and social support. Subjective well-being is an individual's judgment of their life, including the cognitive judgment about life satisfaction and affective judgment of their moods and emotions (Diener et al., 1999). Gratitude is an individual feeling of appreciation to the favor that they receive. They feel abundance; they recognize others' contributions to their happiness and appreciate simple things in their lives (Watkins et al., 2003). Their perception of others' support measures social support. Social support is the kind of support individuals receive from people close to them (relatives/family, colleagues/peers, and significant others) (Zimet et al., 1988).

To measure subjective well-being, we modified and combined items from the 8-item FS (Flourishing Scale) that were developed by Diener and Biswas-Diener (2009) and SPANE (Scale of Positive and Negative Experience), which contain 20 items (6 items measure cognitive, positive and negative affects). A sample item for subjective well-being is: "I lead a purposeful and meaningful life" and "I am engaged and interested in my daily activities." To measure gratitude, we used the Gratitude Resentment and Appreciation Test (GRAT) developed by Watkins et al. (2003) with 44 items to measure the following dimensions: the sense of abundance, simple appreciation, and appreciation of others. A sample taken from this scale is "Life has been good to me," "Often I have been overwhelmed at the beauty of nature," and "I couldn't have gotten where I am today without the help of many people."
Social support is measured by (perceived social support) by developing MSPSS (Multidimensional Scale of Perceived Social Support) from Dahlem et al. (1991). This scale is suitable for the sources of support that the research subjects get: family, peers, superiors, and other significant others (Zimet et al., 1988). This scale contains 12 items. Sample items of this scale are: "I have a special person who is a real source of comfort to me," "I have friends with whom I can share my joy and sorrows", and "There is a special person in my life who cares about my feelings."

Measurement using 20 items of subjective well-being derived from the FS (Flourishing Scale) and SPANE (Scale of Positive and Negative Experience) gave the model fit with Chi-Square = $87.30, \mathrm{df}=68$, P-Value $=.0575$, RMSEA $=.034$, and the entire items are significant. Results from measurement of CFA using GRAT on the variable of gratitude gave the model fit for each dimension: sense of abundance (chi-square $=6.66, \mathrm{df}=5$, $\mathrm{p}$ value $=.24714$, RMSEA $=.037$ ), simple appreciation (chi-square $=7.91, \mathrm{df}=5$, $\mathrm{p}$-value $=$ .16121, RMSEA $=.049$ ), and appreciation for others (chi-square $=1.61, \mathrm{df}=3$, $\mathrm{p}$-value $=.65775$, RMSEA $=.000)$. Meanwhile, the results of measurement CFA MSPSS for the variable of social support gave the model fit on the entire dimensions of family support with chi-square = $0.00, \mathrm{df}=0, \mathrm{p}$-value $=1.00000$, RMSEA $=.000$. This dimension got this value in MSPSS because the model just identified. Alpha Cronbach test on the entire scales showed the reliability of .804 for subjective well-being, .727 for the scale of gratitude, and an alpha score of 797 for perceived social support. 
Table 1

Summarized Regression Analysis

\begin{tabular}{lcl}
\hline \multicolumn{1}{c}{ Model/Variables/Dimensions } & $\mathrm{R}^{2} /$ Beta/R $\mathrm{R}^{2}$ change & Sig. \\
\hline All models & .441 & .000 \\
Gratitude & .397 & .000 \\
Social Support & .044 & .015 \\
Sense ofabundance & .235 & .000 \\
Simpleappreciation & .098 & .000 \\
Appreciationforothers & .064 & .000 \\
Family support & .040 & .000 \\
Peer support & .003 & .313 \\
Agency support & .001 & .486 \\
\hline
\end{tabular}

\section{Results}

This study's subjects were 299 fishermen living in the Pelabuhan Ratu, Sukabumi, West Java. They are male, aged between 19-60: (47.9\% aged 40-50), (47.1\% aged 21-400), (3.8\% aged above 50$)$, and ( $0.8 \%$ aged under 21). Multiple regression analysis showed the value of $\mathrm{R}^{2}=.441$, with a significance of .000 . It means that the variant proportions of subjective well-being, which are made manifest by the variables of gratitude and perceived social support of $44.1 \%$. In comparison, variables beyond this scope of this study gave $55.9 \%$ contribution. It means that the entire independent variables have a significant effect on subjective well-being. The next step is to investigate whether the entire dimensions of the independent variable significantly affect subjective well-being. Table 1 presents three variables with a significant regression coefficient: 1) sense of abundance; 2) appreciation of for others; 3 ) family support (in this case, peer and superior support is not significant). The greatest contributor is the variable of gratitude (0.397), specifically from the sense of abundance with a score of 0.235 . It means that $39.7 \%$ contribution of gratitude and perceived social support is derived from the dimension of sense of abundance $(23,5 \%)$ and simple appreciation $(9,8 \%)$.

\section{Discussion}

This study focused on the factors that affect fishermen's subjective well-being. Subjective wellbeing is defined as the way individuals judge their own lives. Such judgment is related to their satisfaction or dissatisfaction about parts of their lives (cognitive evaluation), including the presence of the negative or positive feelings (positive and negative affect) [see, for example, Bradburn, 1969; Diener et al., 1999; Diener \& Chan, 2011; Proctor et al., 2011]. Piscatorial job is among the oldest forms of employment in the world. Catching fish in the open sea is always associated with grave danger, but it is also exciting. It is no wonder that many fishermen find their occupation rewarding despite the high rate of at-sea mortality. Being a fisherman is dangerous yet awe-inspiring (Anna et al., 2019). Indonesian fishermen have earned the reputation of the most dauntless seafarers.

The multiple regression analysis results have shown that gratitude and perceived social support (including their respective dimensions) 
have significant effects on the fishermen's subjective well-being. Grateful individuals who get positive support from their families exhibit positive emotions that manifest themselves in high morale and a positive attitude towards life. Despite their hard lives, they are always grateful, especially when returning home with many fish (personal interview, 2019). Positive emotions can boost fishermen's morale when they are on the high seas (Fredrickson, 2001). Positive emotions eventually support individuals' judgment of their subjective well-being (Diener et al., 1991), despite the fact that they are economically marginalized. According to broaden-and-build theory (Fredrickson, 2001), experienced positive emotions can assist them in building enduring personal resources (Fredrickson, 2001). The feeling of satisfaction is a subjective moment (Ryan \& Deci, 2001) that encompasses pleasures of both body and mind (Kubovy, 1999), including the pleasant moments (Kahneman et al., 1998). Efforts to maximize happy feelings can help positive affect (positive affect) and negate the negative affect (Deci \& Ryan, 2008). The fishermen show the happy and flourishing feeling they experience when they come home to their families with the abundant harvest after grappling with ferocious storms and lashing winds.

Regressing effects of both variables' dimensions show that only the whole dimensions of gratitude (sense of abundance, simple appreciation, and appreciation for others) and one dimension of family support significantly affect fishermen's subjective well-being other dimensions (peer and agency support) have less significant effects. The significance of the sense of abundance shows those fishermen's religious side: those men perceive and treat the sea and its natural wealth as a divine gift. Amidst the apparent poverty they live in, they are still grateful because the sea and the natural wealth it offers are God's gift that they should be grateful for.

Al-Ghazali (2008) mentions that gratitude means human's awareness of the presence of God Almighty that bestows upon human's tangible and tactile pleasures of life. Froh, Yurkewicz, and Kashdan (2009) explain that showing gratitude daily can help individuals get stronger positive feelings. The simple appreciation dimension shows fishermen's gratitude for the fortune that God gives them. The dimension of appreciation for others helps explain the collective nature of piscatorial job: they must support and rely on one another when fishing on the same vessel. They can still crack a smile on their faces even when they bring so little for their families back home. When embarking to the open sea, usually they are in the company of more than three other fishermen (the exact number of the crew does vary, depending on the fishing boat's size and tonnage). Appreciation of their fellow fishermen's contributions to their collective success is of paramount importance. They show this kind of camaraderie by frequenting coffee shops together upon coming back onshore. Algoe et al. (2008) conclude that individuals who appreciate others' involvement in the good things in their lives help make them better persons with a penchant for a good relationship. Habitual gratitude characterizes friendly and lovable people and helps prevent jealousy and depression (Mccullough et al., 2002). Therefore, gratitude can be perceived as one of the character strengths (Park, 2004). This characteristic is consistently associated with life satisfaction (Park et al., 2004). 
Regression analysis also demonstrated that, out of perceived social support dimensions, only one dimension (family support) proved to have significantly affected the fishermen's subjective well-being. The other two dimensions (peer support and agency support) have no significant effects. Family support is needed for individual's life satisfaction (Nauffal et al., 2013). This statement confirms Gülaçt (2010) who finds family as the most significant dimension affecting subjective well-being. Individuals' perception of the positive support given by the significant others is closely related to their well-being (Major \& Schmader, 1998).

For fishermen, family which represents closest group in their lives give the necessary emotional support before going to the sea and upon their return, especially during the western monsoon when it is hard to catch fish because of the rough winds. The kind of family support they need varies across fishermen and depends on their individual situations (Hasibuan et al., 2018). Nevertheless, family support is what they need most, apart from the endorsement they get from their peers and agencies or supervisors. The pressure they get during hard times when they cannot to fishing due to extreme weathers will be more bearable when their family members show some understanding and cooperation, thus the domestic harmony is preserved. Emotional support, personal attention, appreciation, and little favors that show empathy and thoughtfulness will bring comfort to the fishermen.

The above support is needed because it will affect how fishermen perform as the breadwinner for their families during hard times when they must refrain from going to sea. The whims of nature dictate fishing job, so it is not surprising that fishermen seldom enjoy financial security. This situation is the sole contributor of the high rate of divorce among fishermen. To make the situation even worse, fishermen often find it hard to break away from the habit of gallivanting after a successful fishing mission. Little do they realize that such a habit jeopardizes their families' wellbeing. Fishermen's proclivity to squander their money sparks distrust among family members, and this robs their well-being. In this particular context, family's acceptance and understanding are needed to bolster fishermen's subjective wellbeing.

This study also revealed that simple appreciation, peer support and agency support (significant others) do not significantly affect fishermen's subjective well-being. This is a very intriguing fact which can only be understood if we look into the values adopted by fishermen's community and the people living in the coastal regions. This finding contradicts previous studies which found that peers and other significant others affect individuals' subjective well-being (see, for example, Nauffal et al,, 2013). Surprisingly, this study showed that peer support and agency support have no significant effect on fishermen's subjective well-being. The answer lies in coastal people's culture: one can see a subtle rivalry among fishermen: competitive behavior that is not so explicit, and yet greatly affects local people's well-being. Social discrepancy and the sheer pressure of coastal life have sparked jealousy and gossiping among locals in a social system rife with the gaping chasm between the rich and the poor. This situation necessitates concerned parties to empower those people by educating them to adopt behavior that supports the sense of community (Rahmawati, 2017). A sense of community is a necessary social 
ingredient because it maintains social cohesion and helps in conflict resolution, and promotes social harmony-members of society support one another. For example, fishing boat owners can financially support the fishermen when they cannot go fishing.

Interviews with fishermen reveal a deepening rift between owners of the shipping boats and the fishermen. The latter perceive this situation with cynicism. There is a lingering irony among fishermen: they go fishing together, as soulmates, but in their daily lives, they fiercely compete in a blatant display of success, and this is most articulated in a tradition called sawer, in which they squander their hard-earned cash to pamper and romance local singers; they mindlessly waste their money in a fake display of wealth. This particular finding shows that peer support and agency support contradict with the dimension of simple appreciation. While those fishermen cherish the divine blessings in their lives, they stupendously waste their money simply because they want to be regarded as more successful than their fellow fishermen. If they do not join the sawer's revelry, they risk losing peer respect and even losing jobs. Those men cannot feel the otherwise significant sense of abundance, because if they avoid the sawer spectacle, they would be underestimated by their peers and their agencies. The strong distrust they have for their boat mates and agencies or boat owners deprives them of the sense of abundance. Eventually, they resort to drinking and gallivanting. Consequently, a sense of abundance is replaced by a sense of scarcity and entailing complaints. This condition, in turn, will affect their child-rearing and family resilience.

Those fishermen need to develop a sense of tawakkal, an Islamic term that means total servitude and submission to God. Their feeling of gratitude should fortify their family and their subjective well-being. Gratitude will not significantly affect their life quality unless they have a sense of tawakkal or submission. The submission has its roots in Islamic teaching in which individuals show total submission to their God; such submission is based on the firm belief that their life is regulated and taken care of by God. Submission can help ameliorate their stress and give them some peace of mind (see, for example, Husnar, Saniah, \& Nashori, 2017).

\section{Conclusion}

Based on the research findings, we can conclude that gratitude and perceived social support significantly affect our subjects' subjecttive well-being. Multiple regression analysis on the dependent variables yielded insignificant regression coefficients on four variables: 1) sense of abundance, 2) simple appreciation, 3) appreciation for others, and 4) family support. These four dimensions have proved to significantly affect our research subjects' subjective well-being, while the other variables have less-significant effects. The findings of this study slightly differ from those of the previous studies. Still, they do not wholly disprove the existing theories, especially those related to factors affecting fishermen's subjective well-being. This study's findings are useful for the government and the respondents to pay more attention to factors affecting subjective well-being. This study's findings can also delimit findings related to the other factors affecting fishermen's subjective well-being.

Exhaustive and more comprehensive studies must be performed as part of the coordinated efforts to improve factors that potentially affect subjective well-being of coastal people and the 
fishermen, like providing working capital for business startups, inculcating positive mindset, and providing them with the necessary skills to be cultivated when they are not fishing during rough seasons.]

\section{References}

Adriana, G., Pandjaitan, N. K., \& Dharmawan, A. H. (2017). Kohesivitas komunitas nelayan dalam menghadapi perubahan iklim di pesisir Jawa Barat (Studi kasus di pedesaan Jawa Barat). Sodality: Jurnal Sosiologi Pedesaan, 5(1), 67-74.

Al-Ghazali, I. (2008). Membangkitkan energi qolbu. Pustaka Media.

Algoe, S. B., Haidt, J., \& Gable, S. L. (2008). Beyond reciprocity: Gratitude and relationships in everyday life. Emotion, 8(3), 425-429. https://doi.org/10.1037/1528-3542.8.3.425

Alkozei, A., Smith, R., \& Killgore, W. D. S. (2018). Gratitude and subjective wellbeing: A proposal of two causal frameworks. Journal of Happiness Studies, 19(5), 1519-1542. https://doi.org/10.1007/s10902-017-9870-1

Anna, Z., Yusuf, A. A., Alisjahbana, A. S., \& Ghina, A. A. (2019). Are fishermen happier? Evidence from a large-scale subjective well-being survey in a lower-middle-income country. Marine Policy, 106, 103559. https://doi.org/10.1016/j.marpol.2019.103559

Bradburn, N. M. (1969). The structure of psychological well-being. Aldine Publishing Co.

Cohen, S., Underwood, L. G., \& Gottlieb, B. H. (2000). Social support measurement and intervention: A guide for health and social scientists. Oxford University Press.

Crona, B., Nyström, M., Folke, C., \& Jiddawi, N. (2010). Middlemen, a critical social-ecological link in coastal communities of Kenya and Zanzibar. Marine Policy, 34(4), 761-771. https://doi.org/10.1016/j.marpol.2010.01.023

Dahlem, N. W., Zimet, G. D., \& Walker, R. R. (1991). The multidimensional scale of perceived social support: A confirmation study. Journal of Clinical Psychology, 47(6), 756-761. https://doi.org/10.1002/1097-4679(199111)47:6<756::AID-JCLP2270470605>3.0.CO;2-L

Deci, E. L., \& Ryan, R. M. (2008). Facilitating optimal motivation and psychological well-being across life's domains. Canadian Psychology/Psychologie Canadienne, 49(1), 14. https://doi.org/10.1037/0708-5591.49.3.262

Dictionary, T. O. E. (1989). “Gratitude.”https://www.lexico.com/definition/gratitude.

Diebel, T., Woodcock, C., Cooper, C., \& Brignell, C. (2016). Establishing the effectiveness of a gratitude diary intervention on children's sense of school belonging. Educational and Child Psychology, 33(2), 117-129.

Diener, E. (2009). Culture and well-being: The collected works of Ed Diener (Vol. 38). Dordrecht: Springer.

Diener, E., \& Chan, M. Y. (2011). Happy People Live Longer: Subjective Well-Being Contributes to Health and Longevity. Applied Psychology: Health and Well-Being, 3(1), 1-43. https://doi.org/10.1111/j.1758-0854.2010.01045.x

Diener, E., \& Lucas, R. E. (1999). Personality and subjective well-being. In Well-being: Foundations of hedonic psychology (p. 213). Russel Sage Foundation. 
Diener, E., \& Lucas, R. E. (2000). Explaining differences in societal levels of happiness: Relative standards, need fulfillment, culture, and evaluation theory. Journal of Happiness Studies, 1(1), 41-78. https://doi.org/10.1023/A:1010076127199

Diener, E., Sandvik, E., Pavot, W., \& Gallagher, D. (1991). Response artifacts in the measurement of subjective well-being. Social Indicators Research, 24(1), 35-56. https://doi.org/10.1007/BF00292649

Diener, E., \& Seligman, M. E. P. (2002). Very happy people. Psychological Science, 13(1), 81-84. https://doi.org/10.1111/1467-9280.00415

Diener, E., Suh, E. M., Lucas, R. E., \& Smith, H. L. (1999). Subjective well-being: Three decades of progress. Psychological Bulletin, 125(2), 276-302. https://doi.org/10.1037/0033-2909.125.2.276

Diener, E., Wirtz, D., Biswas-Diener, R., Tov, W., Kim-Prieto, C., Choi, D., \& Oishi, S. (2009). New measures of well-being. In E. Diener (Ed.), Assessing well-being: The collected works of Ed Diener (Vol. 39, pp. 247-266). Dordrecht: Springer Science+Business Media B.V. https://doi.org/10.1007/97890-481-2354-4

Dinillah, M. (2017, February 3). Berapa Jumlah Nelayan di RI? Ini Kata Susi. DetikFinance.

Dni. (2019, April 14). Ironi nelayan yang terpinggirkan di negeri yang kaya laut. DetikFinance.

Eddington, N., \& Shuman, R. (2008). Subjective well-being. San Diego: Continuing Psychology Education Inc.

Emmons, R. A., \& McCullough, M. E. (2003). Counting blessings versus burdens: An experimental investigation of gratitude and subjective well-being in daily life. Journal of Personality and Social Psychology, 84(2), 377-389. https://doi.org/10.1037/0022-3514.84.2.377

Farid, M., \& Lazarus, H. (2008). Subjective well-being in rich and poor countries. The Journal of Management Development, 27(10), 1053-1065. https://doi.org/10.1108/02621710810916303

Fauzi, A. (2005). Kebijakan perikanan dan kelautan: Isu, sintesis, dan gagasan. Jakarta: Gramedia Pustaka Utama.

Fredrickson, B. L. (2001). The role of positive emotions in positive psychology: The broaden-and-build theory of positive emotions. American Psychologist, 56(3), 218-226. https://doi.org/10.1037/0003-066X.56.3.218

Froh, J. J., Yurkewicz, C., \& Kashdan, T. B. (2009). Gratitude and subjective well-being in early adolescence: Examining gender differences. Journal of Adolescence, 32(3), 633-650. https://doi.org/10.1016/j.adolescence.2008.06.006

Gülaçt, F. (2010). The effect of perceived social support on subjective well-being. Procedia-Social and Behavioral Sciences, 2(2), 3844-3849. https://doi.org/10.1016/j.sbspro.2010.03.602

Hasibuan, M. A. I., Anindhita, N., Maulida, N. H., \& Nashori, H. F. (2018). Hubungan antara amanah dan dukungan sosial dengan kesejahteraan subjektif mahasiswa perantau. Psikohumaniora: Jurnal Penelitian Psikologi, 3(1), 101. https://doi.org/10.21580/pjpp.v3i1.2214

Husnar, A. Z., Saniah, S., \& Nashori, F. (2017). Harapan, tawakal, dan stres akademik. Psikohumaniora: Jurnal Penelitian Psikologi, 2(1), 94-105. https://doi.org/10.21580/pjpp.v2i1.1179

Kahneman, D., Diener, E., \& Schwarz, N. (1998). Well-being: The foundations of hedonic psychology. Russell Sage Foundation. 
Killen, A., \& Macaskill, A. (2015). Using a Gratitude Intervention to Enhance Well-Being in Older Adults. Journal of Happiness Studies, 16(4), 947-964. https://doi.org/10.1007/s10902-014-9542-3

Kong, F., Zhao, J., \& You, X. (2013). Self-Esteem as Mediator and Moderator of the Relationship Between Social Support and Subjective Well-Being Among Chinese University Students. Social Indicators Research, 112(1), 151-161. https://doi.org/10.1007/s11205-012-0044-6

Kubovy, M. (1999). On the pleasures of the mind. In D. Kahneman, E. Diener, \& N. Schwarz (Eds.), Wellbeing: The foundations of hedonic psychology (pp. 134-154). New York: Russell Sage Foundation.

Lai, S. T., \& O'Carroll, R. E. (2017). 'The three good things'- the effects of gratitude practice on wellbeing: A randomised controlled trial. Health Psychology, 26(1), 10-18.

Li, B., Ma, H., Guo, Y., Xu, F., Yu, F., \& Zhou, Z. (2014). Positive psychological capital: A new approach to social support and subjective well-being. Social Behavior and Personality: An International Journal, 42(1), 135-144. https://doi.org/10.2224/sbp.2014.42.1.135

Major, B., \& Schmader, T. (1998). Coping with stigma through psychological disengagement. In Prejudice (pp. 219-241). Cambridge: Academic Press Elsevier. https://doi.org/10.1016/B978012679130-3/50045-4

Malecki, C. K., \& Demaray, M. K. (2002). Measuring perceived social support: Development of the child and adolescent social support scale (CASSS). Psychology in the Schools, 39(1), 1-18. https://doi.org/10.1002/pits.10004

Malecki, C. K., \& Demaray, M. K. (2006). Social support as a buffer in the relationship between socioeconomic status and academic performance. School Psychology Quarterly, 21(4), 375-395. https://doi.org/10.1037/h0084129

Mccullough, M. E., Emmons, R. A., \& Tsang, J. (2002). The Grateful Disposition: A Conceptual and Empirical Topography. Journal of Personality and Social Psychology, 82(1), 112-127. https://doi.org/10.1037//0022-3514.82.1.112

McCullough, M. E., Kilpatrick, S. D., Emmons, R. A., \& Larson, D. B. (2001). Is gratitude a moral affect? Psychological Bulletin, 127(2), 249-266. https://doi.org/10.1037/0033-2909.127.2.249

Nashir, A. (2017). Kohesivitas budaya siri' masyarakat pesisir kota Makassar dalam perspektif hukum Islam dan pendidikan. Tarbawi: Jurnal Pendidikan Agama Islam, 2(01), 12-23. https://doi.org/10.26618/jtw.v2i01.804

Nauffal, D., Ammar, D., \& Sbeity, R. (2013). The role of perceived social support in predicting subjective wellbeing in Lebanese college students. Journal of Happiness and Well-Being, 1(2), 121-143.

Park, N. (2004). The role of subjective well-being in positive youth development. The ANNALS of the American Academy of Political and Social Science, 591(1), 25-39. https://doi.org/10.1177/0002716203260078

Park, N., Peterson, C., \& Seligman, M. E. P. (2004). Strengths of character and well-being. Journal of Social and Clinical Psychology, 23(5), 603-619. https://doi.org/10.1521/jscp.23.5.603.50748

Proctor, C., Maltby, J., \& Linley, P. A. (2011). Strengths use as a predictor of well-being and health-related quality of life. Journal of Happiness Studies, 12(1), 153-169. https://doi.org/10.1007/s10902009-9181-2

Rahmawati, I. (2017). Nilai sense of community pada kesejahteraan psikologis dalam menghuni (Housing Well-being): Studi meta-analisis. Psikohumaniora: Jurnal Penelitian Psikologi, 2(1), 81-93. https://doi.org/10.21580/pjpp.v2i1.952 
Ryan, R. M., \& Deci, E. L. (2001). On happiness and human potentials: A review of research on hedonic and eudaimonic well-being. Annual Review of Psychology, 52(1), 141-166. https://doi.org/10.1146/annurev.psych.52.1.141

Ryff, C. D. (1989). Happiness is everything, or is it? Explorations on the meaning of psychological wellbeing. Journal of Personality and Social Psychology, 57(6), 1069-1081. https://doi.org/10.1037/0022-3514.57.6.1069

Salsabila, K. (2019). Kohesivitas kelompok nelayan usaha mandiri Belitong di Desa Kurnia Jaya Kecamatan Manggar Kabupaten Belitung Timur. Universitas Pasundan.

Savelkoul, M., Post, M. W. M., De Witte, L. P., \& Van Den Borne, H. B. (2000). Social support, coping and subjective well-being in patients with rheumatic diseases. Patient Education and Counseling, 39(2-3), 205-218. https://doi.org/10.1016/S0738-3991(99)00033-6

Siedlecki, K. L., Salthouse, T. A., Oishi, S., \& Jeswani, S. (2014). The relationship between social support and subjective well-being across age. Social Indicators Research, 117(2), 561-576. https://doi.org/10.1007/s11205-013-0361-4

Snyder, C. R. (2002). Hope theory: Rainbows in the mind. Psychological Inquiry, 13(4), 249-275. https://doi.org/10.1207/S15327965PLI1304_01

Stokes, J. P. (1985). The relation of social network and individual difference variables to loneliness. Journal of Personality and Social Psychology, 48(4), 981-990. https://doi.org/10.1037/00223514.48.4.981

Tov, W., \& Diener, E. (2013). Subjective wellbeing. In K. D. Keith (Ed.), The Encyclopedia of Cross-Cultural Psychology. Wiley Online Library. https://doi.org/10.1002/9781118339893.wbeccp518

Tran, T. Van, \& Wright Jr, R. (1986). Social support and subjective well-being among Vietnamese refugees. Social Service Review, 60(3), 449-459. https://doi.org/10.1086/644387

Waters, L. (2011). A review of school-based positive psychology interventions. The Australian Educational and Developmental Psychologist, 28(2), 75-90. https://doi.org/10.1375/aedp.28.2.75

Watkins, P. C., Woodward, K., Stone, T., \& Kolts, R. L. (2003). Gratitude and happiness: Development of a measure of gratitude, and relationships with subjective well-being. Social Behavior and Personality: An International Journal, 31(5), 431-451. https://doi.org/10.2224/sbp.2003.31.5.431

Wood, A. M., Joseph, S., \& Maltby, J. (2009). Gratitude predicts psychological well-being above the Big Five facets. Personality and Individual Differences, 46(4), 443-447. https://doi.org/10.1016/j.paid.2008.11.012

Zimet, G. D., Dahlem, N. W., Zimet, S. G., \& Farley, G. K. (1988). The multidimensional scale of perceived aocial support. Journal of Personality Assessment, 52(1), 30-41. https://doi.org/10.1207/s15327752jpa5201_2 
This page has been intentionally left blank. 